Jurnal Akuntansi dan Keuangan (JAK)

Volume 6, No. 2 Oktober Tahun 2021

Page: 180 - 196

http://ojs.uho.ac.id/index.php/jak-uho/issue/archive

e-ISSN: 2088-4656

\title{
ANALISIS PENERAPAN SISTEM AKUNTANSI KEUANGAN DAERAH PADA BADAN PENGELOLAAN KEUANGAN ASET \& PENDAPATAN DAERAH KABUPATEN MUNA BARAT
}

\author{
La Ode Anto ${ }^{1}$, Ishak Awaluddin ${ }^{2}$, Try Edi Suwarno ${ }^{3}$ \\ Jurusan Akuntansi Fakultas Ekonomi dan Bisnis Universitas Halu Oleo Kendari \\ Sulawesi Tenggara
}

\begin{abstract}
Abstrak
Penelitian ini bertujuan untuk mengetahui kesesuaian penerapan Sistem Akuntansi Keuangan Daerah pada Badan Pengelolaan Keuangan Aset dan Pendapatan Daerah Kabupaten Muna Barat terhadap Standar Akuntansi Pemerintahan dan Pedoman Pengelolaan Keuangan Daerah. Teknik analisis data yang digunakan dalam penelitian ini adalah analisis deskriptif kualitatif. Pengumpulan data penelitian menggunakan teknik wawancara (interview) dan dokumentasi.

Hasil penelitian ini menunjukan bahwa Badan Pengelolaan Keuangan Aset dan Pendapatan Daerah menggunakan Aplikasi SIMDA Keuangan dan Microsoft Excel yang membantu pengelolaan data keuangan pemerintah daerah. Penerapan SIMDA Keuangan sebagai Sistem Akuntansi Keuangan Daerah di Badan Pengelolaan Keuangan Aset dan Pendapatan Daerah Kabupaten Muna Barat saat ini belum begitu efektif. Hal tersebut terkait dengan masalah infrastruktur berupa jaringan dan fasilitas yang memadai dan masalah kesiapan Sumber Daya Manusia. Penyusunan Laporan Keuangan SKPD BPKAPD yang terdiri dari : 1) Laporan Realisasi Anggaran, 2) Laporan Operasional 3) Neraca, 4) Laporan Perubahan Ekuitas 5) Catatan Atas Laporan Keuangan.
\end{abstract}

Kata Kunci : Sistem Akuntansi Keuangan Daerah, SIMDA, Laporan Keuangan.

Abstract

This study aims to determine the suitability of the application of the Regional Financial Accounting System at the Regional Financial Management Agency for Assets and Revenues of West Muna Regency to Government Accounting Standards and Guidelines for Regional Financial Management. The data analysis technique used in this research is descriptive qualitative analysis. Collecting research data using interview techniques (interview) and documentation.

The results of this study indicate that the Regional Asset and Revenue Financial Management Agency uses SIMDA Finance and Microsoft Excel applications that help manage local government financial data. The implementation of SIMDA Finance as a Regional Financial Accounting System in the Regional Asset and Revenue Financial Management Agency of West Muna Regency is currently not very effective. This is related to infrastructure problems in the form of adequate networks and facilities and issues of the readiness of Human Resources. Preparation of BPKAPD SKPD Financial Statements consisting of: 1) Budget Realization Report, 2) 
Jurnal Akuntansi dan Keuangan (JAK)

Volume 6, No. 2 Oktober Tahun 2021

Page: 180 - 196

http://ojs.uho.ac.id/index.php/jak-uho/issue/archive

e-ISSN: 2088-4656

Operational Report 3) Balance Sheet, 4) Change in Equity Report 5) Notes to Financial Statements.

Keywords: Regional Financial Accounting Systems, SIMDA, Financial Statements.

\section{PENDAHULUAN}

Perubahan sistem pemerintahan dari sistem terpusat menjadi sistem otonomi daerah telah memberi dampak yang besar pada penyelenggaraan pemerintahan dan ruang lingkup kerja pada umumnya. Menurut Undang-Undang Nomor 23 tahun 2014, otonomi daerah mengandung arti bahwa daerah diberi kesempatan untuk mandiri dalam mengatur dan mengurus urusan rumah tangganya sendiri, dengan menggali dan memanfaatkan sumber-sumber ekonomi yang ada untuk kesejahteraan dan kemakmuran masyarakat di daerah berdasarkan prinsip-prinsip demokrasi, prinsip pemerataan dan keadilan, peran, serta prakarsa dan aspirasi masyarakat sendiri serta sesuai dengan kondisi, potensi dan keanekaragaman wilayahnya.

Kabupaten Muna Barat merupakan salah satu daerah otonom yang ada di Sulawesi Tenggara yang telah melaksanakan prinsip-prinsip otonomi daerah dengan berusaha mengimplementasikan sistem pengukuran kinerja demi terselenggaranya pelayanan publik yang lebih baik. Badan Pengelolaan Keuangan Aset dan Pendapatan Daerah (BPKAPD) Kabupaten Muna Barat sebagai salah satu Satuan Kerja Perangkat Daerah (SKPD) di lingkungan pemerintah Kabupaten Muna Barat dalam mendukung visi dan misi Kabupaten Muna Barat dan sebagai bentuk implementasi pelaksanaan tugas berdasarkan peraturan pemerintah tentang susunan organisasi pemerintah, dan dilahirkan tugas pokok (tupoksi) yaitu membantu Bupati menyelenggarakan kewenangan pemerintah daerah dibidang pengelolaan keuangan dan aset daerah serta tugas lain yang diberikan bupati sesuai ruang lingkup tugas dan fungsinya. Namun dibalik itu tentunya harus tetap berlandaskan undang-undang dan peraturan pemerintah yang ada.

Dalam hal pengelolaan keuangan daerah sebagai penanggungjawab yang mendelegasikan kepada bawahannya sesuai dengan instansi yang berkompeten tentang keuangan daerah. Pengelolaan keuangan daerah merupakan salah satu bagian yang mengalami perubahan mendasar dengan ditetapkannya UU No.23 Tahun 2014 tentang Pemerintah Daerah dan UU No.33 Tahun 2004 tentang Perimbangan Keuangan antara Pemerintah Pusat dan Pemerintah Daerah. Kedua Undang-Undang tersebut telah memberikan kewenangan lebih luas kepada pemerintah daerah. Kewenangan dimaksud diantaranya adalah keleluasaan dalam mobilisasi sumber dana, menentukan arah, tujuan dan target penggunaan anggaran. Pengelolaan keuangan daerah merupakan suatu kegiatan yang akan mempengaruhi peningkatan kesejahteraan dan kemakmuran rakyat dan bangsa Indonesia. Kewajiban Pemerintah Pusat dan Daerah untuk menyusun laporan keuangan sebagai wujud akuntabilitas pengelolaan keuangan negara/daerah.

Peraturan Menteri Dalam Negeri Nomor 21 tahun 2011 tentang perubahan kedua atas Peraturan Menteri Dalam Negeri nomor 13 tahun 2006 yang memuat pedoman dalam penerapan Sistem Akuntansi Keuangan Daerah (SAKD). SAKD 
Jurnal Akuntansi dan Keuangan (JAK)

Volume 6, No. 2 Oktober Tahun 2021

Page: 180 - 196

http://ojs.uho.ac.id/index.php/jak-uho/issue/archive

e-ISSN: 2088-4656

merupakan penyempurnaan dari sistem pengelolaan keuangan daerah sebelumnya, dimana SAKD sudah menggunakan metode pencatatan ganda (double entry) dengan sistem akuntansi berbasis kas modifikasi yang mengarah kepada basis akrual (accrual basis). Disamping itu penerapan SAKD juga ditempatkan dalam upaya mencapai komputerisasi dalam organisasi pemerintah. Penerapan SAKD diharapkan akan menghasilkan catatan dan laporan atas transaksi keuangan yang terjadi dalam organisasi (entitas) pemerintah daerah menjadi lebih akurat, tepat dan komprehensif, sehingga dapat memperbaiki kualitas keputusan yang diambil pemakai laporan keuangan tersebut.

Dalam struktur pemerintah daerah, Satuan Kerja Perangkat Daerah (SKPD) merupakan entitas akuntansi yang mempunyai kewajiban melakukan pencatatan atas transaksi pendapatan, belanja, aset, dan selain kas yang terjadi di lingkungan satuan kerja. Dalam proses pencatatan tersebut dilakukan oleh Pejabat Penatausahaan Keuangan Satuan Kerja Perangkat Daerah (PPK-SKPD) dan pada akhir periode dari catatan tersebut PPK-SKPD menyusun laporan keuangan untuk satuan kerja bersangkutan.

Badan Pengelolaan Keuangan Aset dan Pendapataan Daerah (BPKAPD) sebagai Entitas Akuntansi \& Pelaporan melakukan pencatatan transaksi yaitu: (1) Transaksi-transaksi yang dilakukan oleh SKPD sebagai satuan kerja yaitu mencatat transaksi keuangan dalam melaksanakan program dan kegiatan yang ada pada BPKAPD. (2) Transaksitransaksi yang dilakukan oleh SKPKD sebagai pemerintah daerah untuk mencatat transaksi keuangan, seperti pendapatan yang berasal dari dana perimbangan dan pendapatan hibah, belanja bunga, belanja subsidi, belanja hibah, belanja bantuan sosial, belanja bagi hasil, belanja bantuan keuangan, dan belanja tidak terduga, serta penerimaan pembiayaan dan pengeluaran pembiayaan daerah.

Dalam Standar Akuntansi Pemerintahan Nomor 71 Tahun 2010 menyebutkan bahwa ciri keuangan pemerintah yang penting bagi pengendalian salah satunya ialah aset tetap sebagai sumber daya ekonomi karena digunakan dalam kegiatan operasional pemerintahan. Jumlah aset tetap pada Neraca tahun 2019 Badan Pengelolaan Keuangan Aset \& Pendapatan Daerah Kabupaten Muna Barat dapat dilihat pada Tabel 1.1 berikut :

Tabel 1.1 Aset Tetap BPKAPD Kabupaten Muna Barat

\begin{tabular}{|l|l|l|}
\hline No & Nama Aset Tetap & Nilai \\
\hline 1. & Tanah & 0,00 \\
\hline 2. & Peralatan dan Mesin & $4.026 .501 .318,00$ \\
\hline 3. & Gedung dan Bangunan & 0,00 \\
\hline 4. & Jalan,Irigasi, dan Jaringan & 0,00 \\
\hline 5. & Aset tetap lainnya & 0,00 \\
\hline 6. & Kontruksi Dalam Pengerjaan & 0,00 \\
\hline 7. & Akumulasi Penyusutan & $(1.895 .860 .047,00)$ \\
\hline & Total Aset Tetap & $\mathbf{2 . 1 3 0 . 6 4 1 . 2 7 1 , 0 0}$ \\
\hline
\end{tabular}

Sumber : Laporan Penyelenggaraan Pemerintah Daerah Kabupaten Muna Barat 2019 
Jurnal Akuntansi dan Keuangan (JAK)

Volume 6, No. 2 Oktober Tahun 2021

Page: 180 - 196

http://ojs.uho.ac.id/index.php/jak-uho/issue/archive

e-ISSN: 2088-4656

Pengakuan tanah, gedung dan bangunan, jalan, irigasi dan jaringan, aset tetap lainnya, dan konstruksi dalam pengerjaan Badan Pengelolaan Keuangan Aset \& Pendapatan Daerah tidak melakukan pencatatan nilai aset tetap tersebut yang seharusnya aset tetap diakui pada saat aset tetap telah diterima atau diserahkan hak kepemilikannya dan/atau pada saat penguasaan nya berpindah atau telah siap dipakai, hal tersebut sesuai dengan PSAP 07 Paragraf 18. Akibatnya aset tetap yang disajikan dalam laporan keuangan yaitu neraca tidak berdasarkan pada kondisi yang sebenarnya dan tidak dapat diandalkan keakuratan nya.

\section{LANDASAN TEORI}

\section{a. Sistem Akuntansi Keuangan Daerah}

Keuangan daerah dapat diartikan sebagai semua hak dan kewajiban yang dapat dinilai dengan uang, demikian pula segala sesuatu baik berupa uang maupun barang yang dapat dijadikan kekayaan daerah sepanjang belum dimiliki/dikuasai oleh negara atau daerah yang lebih tinggi serta pihak-pihak lain sesuai ketentuan/peraturan perundangan yang berlaku (Abdul Halim, 2012:18). Sedangkan sistem akuntansi keuangan daerah diartikan sebagai sistem yang mengolah semua transaksi keuangan, aset, kewajiban, dan ekuitas dana pemerintah daerah yang menghasilkan informasi keuangan yang tepat waktu dengan mutu dapat diandalkan (Indra Bastian, 2011:151).

\section{b. Penyusunan Laporan Keuangan SKPD}

Berikut ini adalah penyusunan laporan keuangan yang komprehensif dan dilaksanakan pada tingkatan SKPD :

Tabel 2.4 Jenis Laporan Keuangan Masing-Masing Level

\begin{tabular}{|l|c|c|}
\hline \multicolumn{1}{|c|}{ Jenis Laporan Keuangan } & SKPD & $\begin{array}{c}\text { PPKD } \\
\text { (Konsolidator) }\end{array}$ \\
\hline Laporan Realisasi Anggaran (LRA) & Ya & Ya \\
\hline Laporan Operasional (LO) & Ya & Ya \\
\hline Neraca & Ya & Ya \\
\hline Laporan Perubahan Ekuitas (LPE) & Ya & Ya \\
\hline Laporan Perubahan SAL & Tidak & Ya \\
\hline Laporan Arus Kas & Tidak & Ya \\
\hline Catatan Atas Laporan Keuangan & Ya & Ya \\
\hline
\end{tabular}

1. Menyusun LRA

Berdasarkan Neraca Saldo yang telah disesuaikan, Akuntansi SKPD mengidentifikasi akun-akun yang termasuk dalam komponen Laporan Realisasi Anggaran dan kemudian disajikan dalam "Laporan Realisasi Anggaran".

2. Menyusun LO 
Jurnal Akuntansi dan Keuangan (JAK)

Volume 6, No. 2 Oktober Tahun 2021

Page: 180 - 196

http://ojs.uho.ac.id/index.php/jak-uho/issue/archive

e-ISSN: 2088-4656

Berdasarkan Neraca Saldo setelah Penutupan LRA, Akuntansi SKPD mengidentifikasi akun-akun yang termasuk dalam komponen Laporan Operasional untuk kemudian disajikan dalam Laporan Operasional.

3. Menyusun Neraca

Berdasarkan Neraca Saldo setelah Penutupan LO, Akuntansi SKPD membuat Neraca.

4. Menyusun Laporan Perubahan Ekuitas

Selanjutnya, Akuntansi SKPD membuat Laporan Perubahan Ekuitas menggunakan data Ekuitas Awal dan data perubahan ekuitas periode berjalan yang salah satunya diperoleh dari Laporan Operasional yang telah dibuat sebelumnya. Laporan Perubahan Ekuitas ini akan menggambarkan pergerakan ekuitas SKPD.

5. Menyusun Catatan atas Laporan Keuangan

Catatan atas Laporan Keuangan meliputi penjelasan naratif atau rincian dari angka yang tertera dalam Laporan Realisasi Anggaran, Laporan Operasional, Neraca, dan Laporan Perubahan Ekuitas.

\section{METODE PENELITIAN}

\section{a. Objek Penelitian}

Penelitian ini dilakukan pada Badan Pengelolaan Keuangan Aset dan Pendapatan Daerah Kabupaten Muna Barat. Objek dalam penelitian ini adalah laporan keuangan SKPD Badan Pengelolaan Keuangan Aset dan Pendapatan Daerah Kabupaten Muna Barat.

\section{b. Jenis dan Sumber Data}

Jenis data yang digunakan dalam penelitian ini adalah :

1. Data kualitatif

Data kualitatif adalah bahan keterangan dalam bentuk uraian kata-kata yang tidak dapat diukur dalam skala numerik. Dalam penelitian ini, data kualitatif nya berupa pertanyaan deskriptif yang diperoleh dari hasil wawancara pada Badan Pengelolaan Keuangan Aset dan Pendapatan Daerah Kabupaten Muna Barat.

2. Data Kuantitatif

Data kuantitatif adalah data yang disajikan dalam bentuk angka- angka dan tabel yang diperoleh dari penjumlahan dan pengukuran. Data kuantitatif dalam penelitian ini adalah laporan Keuangan SKPD pada Badan Pengelolaan Keuangan Aset dan Pendapatan Daerah Kabupaten Muna Barat.

Sumber data dalam penelitian ini berupa data primer adalah data yang diperoleh langsung dari sumber asli (tanpa perantara). Data dalam penelitian ini 
Jurnal Akuntansi dan Keuangan (JAK)

Volume 6, No. 2 Oktober Tahun 2021

Page: 180 - 196

http://ojs.uho.ac.id/index.php/jak-uho/issue/archive

e-ISSN: 2088-4656

diperoleh langsung dengan melakukan wawancara (Interview) kepada pihak-pihak yang terkait. Data sekunder merupakan sumber data penelitian yang diperoleh dari proses dokumentasi. Data yang diperoleh dari dokumentasi adalah gambaran umum, struktur organisasi, laporan keuangan SKPD Badan Pengelolaan Keuangan Aset dan Pendapatan Daerah Kabupaten Muna Barat.

c. Metode Pengumpulan Data

Metode yang digunakan dalam pengumpulan data yang dibutuhkan dalam penilitian yaitu:

1. Interview, berupa wawancara atau tatap langsung dengan pimpinan dan pegawai pada pegawai pada instansi tersebut.

2. Dokumentasi, yaitu pengumpulan data melalui laporan-laporan serta dokumen Pemerintah Kabupaten Muna.

\section{d. Metode Analisis}

Metode yang digunakan dalam penelitian ini adalah metode analisis deskriptif kualitatif. Metode analisis deskriptif kualitatif dalam suatu penelitian berguna untuk mengembangkan teori yang telah dibangun dari data yang sudah didapatkan di lapangan. Pada tahap awal peneliti menggambarkan secara sistematis, faktual dan akurat mengenai fakta-fakta serta hubungan antara fenomena yang diselidiki. Kemudian dilakukan pengumpulan data secara rinci, mulai dari observasi hingga penyusunan laporan (Sugiyono, 2008).

Adapun prosedur dari analisis data adalah sebagai berikut:

1. Tahap pengumpulan data melalui instrumen pengumpulan data.

2. Tahap editing, yaitu memeriksa kejelasan dan kelengkapan pengisian instrumen pengumpulan data.

3. Tahap pengkodean, yaitu proses identifikasi dan klasifikasi dari tiap pertanyaan yang terdapat dalam instrument pengumpulan data.

4. Tahap penyajian data dengan merangkai data menjadi satu kesatuan agar dapat dirumuskan kesimpulan dengan melakukan tinjauan ulang di lapangan serta mendapatkan hasil yang valid.

\section{HASIL DAN PEMBAHASAN}

a. Hasil

Sistem Akuntansi Keuangan Daerah Badan Pengelolaan Keuangan Aset \& Pendapatan Daerah

Untuk menyelenggarakan akuntansi pemerintah daerah, Kepala BPKAD Kabupaten Muna Barat menerapkan sistem akuntansi Keuangan Daerah dengan mengacu pada peraturan daerah tentang pokok-pokok pengelolaan keuangan daerah. Dengan diterbitkan beberapa Peraturan Bupati Kabupaten Muna Barat yaitu: 
Jurnal Akuntansi dan Keuangan (JAK)

Volume 6, No. 2 Oktober Tahun 2021

Page: 180 - 196

http://ojs.uho.ac.id/index.php/jak-uho/issue/archive

e-ISSN: 2088-4656

a. Peraturan Bupati Muna Barat nomor 11 tahun 2016 tentang kebijakan akuntansi pemerintah kabupaten Muna Barat

b. Peraturan Bupati Muna Barat nomor 12 tahun 2016 tentang sistem akuntansi pemerintah kabupaten Muna Barat

c. Peraturan Bupati Muna Barat nomor 30 tahun 2017 tentang kedudukan, tugas pokok dan fungsi serta tata kerja Badan Pengelola Keuangan, Aset, dan Pendapatan Daerah Kabupaten Muna Barat

Sistem akuntansi keuangan daerah berdasarkan Permendagri nomor 13 tahun 2006 yang disesuaikan dengan SAP berbasis akrual PP nomor 71 tahun 2010 yaitu meliputi serangkaian prosedur mulai dari proses pengumpulan data, pencatatan, penggolongan dan peringkasan atas transaksi atau kejadian keuangan serta pelaporan keuangan dalam rangka pertanggungjawaban pelaksanaan APBD yang dapat dilakukan secara manual atau menggunakan aplikasi komputer.

Salah satu bentuk pemanfaatan teknologi direalisasikan dalam bentuksistem informasi terkomputerisasi yang disebut Sistem Informasi ManajemenDaerah (SIMDA). SIMDA dirancang oleh Badan Pengawas Keuangan danPembangunan (BPKP) yang merupakan suatu sistem informasi yang dibangun,dikembangkan dan digunakan untuk melakukan proses penyusunan AnggaranPendapatan dan Belanja Daerah (APBD). BPKP sesuai dengan fungsinya sebagaiinternal auditor dan sebagai pengemban amanat pembina penyelenggara SistemPengendalian Intern Pemerintah (SPIP) sesuai PP Nomor 60 tahun 2008mengembangkan SIMDA dengan mengacu pada ketentuan Perundang-undangandan praktik pengelolaan keuangan pemerintah daerah berdasarkan PermendagriNomor 13 tahun 2006 tentang Pedoman Pengelolaan Keuangan Daerah.

Badan Pengelolaan Keuangan Aset \& Pendapatan Daerah Kabupaten Muna Barat sudah menerapkan Sistem InformasiManajemen Daerah (SIMDA) akan tetapi masih tetap juga menggunakan sistem manual atau penyusunannya menggunakan Microsoft Excel. Hal ini sesuai dengan hasil wawancara dengan staf bidang Akuntansi BPKAPD, yang menyatakan bahwa :

“ dalam penerapan sistem akuntansi keuangan daerah di Badan Pengelolaan Keuangan Aset dan Pendapatan Daerah Kab. Muna Barat menggunakan aplikasi SIMDA tetapi untuk hasilnya masih menggunakan Microsoft Excel atau manual hanya peng input an dan proses pencairan yang menggunakan aplikasi SIMDA"

Yang menyebabkan pengelolaan keuangan di BPKAPD masih dilakukan secara manual dan tidak menggunakan SIMDA secara keseluruhan disebabkan beberapa hal. Hal ini diungkapkan oleh staf Bidang Akuntansi yang mengatakan bahwa :

" ketika penyusunan laporan keuangan aplikasi SIMDA yang digunakan tidak bisa dipakai dikarenakan database komputer error jadi agar ada laporan keuangannya dialihkan ke manual"

Ada beberapa kendala yang dihadapi oleh BadanPengelolaan Keuangan Aset \& Pendapatan Daerah Kabupaten Muna Barat didalam menjalankan sistem tersebut 
Jurnal Akuntansi dan Keuangan (JAK)

Volume 6, No. 2 Oktober Tahun 2021

Page: 180 - 196

http://ojs.uho.ac.id/index.php/jak-uho/issue/archive

e-ISSN: 2088-4656

untuk pelaksanaan pengelolaankeuangan daerah, hal ini tersirat dalam wawancara staf bidang akuntansi sebagai berikut:

"kalau berbicara kendala sebenarnya bukan hanya dari teknologi nya yaitu database tapi ada juga dari Sumber Daya Manusianya, jangankan hanya di BPKAPD, Muna Barat untuk di setiap SKPD nya SDM itu yang kurang dalam memahami sistem yang ada yaitu SIMDA keuangan"

Faktor dukungan infrastruktur dan kesiapan SDM dalam penerapan SAKD diungkapkan dalam wawancara olah staf bidang Akuntansi yang mengoperasikan SIMDA yang mengatakan bahwa :

"kalau berbicara infrastruktur sebenarnya jaringan yang terutama, jaringan yang kurang memadai terus kantor juga tidak kondusif / tidak memadai karena beberapa kantor di Muna Barat hanya meminjam gedung termasuk keuangan yang hanya menumpang ke kantor-kantor yang lain terus kesiapan SDM nya ini kurang karena sedikitnya pelatihan dari PEMDA nya sendiri terus kalau berbicara SDM di Muna Barat itu rata-rata SDM nya bukan PNS tapi kebanyakan itu yang menjalankan aplikasi itu honorer atau tenaga kontrak"

Dengan penerapan SIMDA sebagai sistem akuntansi Keuangan daerah mempengaruhi kualitas laporan keuangan Pemerintah Daerah Kabupaten Muna Barat. Hal ini disampaikan oleh staf bidang Akuntansi, yang mengungkapkan bahwa: "sebenarnya kalau berbicara kualitas aplikasi itu memang menyediakan informasi yang lengkap cuman di akhirnya saja untuk di bagian penyusunan laporan keuangan tidak bisa menghasilkan laporan keuangan. Kalau berbicara aplikasi itu sebenarnya itu prosesnya hanya untuk memudahkan dalam penginputan pelaporan pertanggungjawaban nya laporan realisasi, penginputan BKU, penginputan SP2D, proses-proses pencairan, dan pelaporan tetapi itu hanya untuk menghasilkan SP2D dan laporan akhirnya itu hanya LRA saja. Tapi kalau hanya untuk laporan keuangan yang seperti 5 macam laporan keuangan hanya 1 saja yang menggunakan SIMDA sisanya disusun mengunakan Microsoft Excel”

\section{Laporan Keuangan Badan Pengelolaan Keuangan Aset \& Pendapatan Daerah}

Peraturan Pemerintah Nomor 71 Tahun 2010 tentang Kerangka Konseptual Akuntansi Pemerintah merupakan peraturan pemerintah yang masih digunakan sebagai acuan dalam penyusunan laporan keuangan Badan Pengelolaan Keuangan Aset \& Pendapatan Daerah (BPKAPD) Kabupaten Muna Barat.

Badan Pengelolaan Keuangan Aset \& Pendapatan Daerah (BPKAPD) Kabupaten Muna Barat sebagai entitas pelaporan, melaporkan tujuh (7) laporan keuangan tersebut karena sudah mencakup seluruh SKPD yang ada di Kabupaten Muna Barat. Namun, dalam penyusunan laporan keuangan Badan Pengelolaan Keuangan Aset \& Pendapatan Daerah (BPKAPD) Kabupaten Muna Barat sebagai entitas akuntansi dimana hanya satu SKPD saja melaporkan lima (5) laporan keuangan 
Jurnal Akuntansi dan Keuangan (JAK)

Volume 6, No. 2 Oktober Tahun 2021

Page: 180 - 196

http://ojs.uho.ac.id/index.php/jak-uho/issue/archive

e-ISSN: 2088-4656

yang terdiri dari Laporan Realisasi Anggaran, Neraca, Laporan Operasional, Laporan Perubahan Ekuitas, dan Catatan atas Laporan Keuangan.

\section{b. Pembahasan}

Analisis Sistem Akuntansi Keuangan Daerah Badan Pengelolaan Keuangan Aset \& Pendapatan Daerah

Untuk menyelenggarakan akuntansi pemerintah daerah, Kepala BPKAD Kabupaten Muna Barat menerapkan sistem akuntansi Keuangan Daerah dengan mengacu pada peraturan daerah tentang pokok-pokok pengelolaan keuangan daerah. Peraturan dibuat dengan berpedoman pada Peraturan Pemerintah Nomor 60 tahun 2008 tentang Sistem Pengendalian Intern Pemerintah dan Peraturan Pemerintah nomor 71 tahun 2010 tentang Standar Akuntansi Pemerintah.

Untuk menerapkan Sistem Akuntansi Keuangan Daerah yang berdasarkan Permendagri nomor 13 tahun 2006 yang disesuaikan dengan SAP berbasis akrual PP nomor 71 tahun 2010. Maka Badan Pengelolaan Keuangan Aset dan Pendapatan Daerah menggunakan Aplikasi SIMDA Keuangan dan Microsoft Excel yang membantu pengelolaan data keuangan pemerintah daerah. Hal ini telah sesuai dengan penerapan SIMDA keuangan umum menurut BPKP yaitu meliputi serangkaian prosedur mulai dari proses pengumpulan data, pencatatan, penggolongan dan peringkasan atas transaksi atau kejadian keuangan serta pelaporan keuangan dalam rangka pertanggungjawaban pelaksanaan APBD yang dapat dilakukan secara manual atau menggunakan aplikasi komputer.

Ada beberapa kendala yang dihadapi oleh Badan Pengelolaan Keuangan Aset \& Pendapatan Daerah Kabupaten Muna Barat di dalam menjalankan sistem tersebut untuk pelaksanaan pengelolaan keuangan daerah, yaitu faktor dukungan infrastruktur dan kesiapan SDM. Dalam pengoperasian SIMDA keuangan kurangnya infrastruktur berupa jaringan dan fasilitas yang memadai yang berakibat database aplikasi error. Sarana yang diperlukan dalam penggunaan SIMDA tergolong sederhana. Sarana yang diperlukan hanya berupa komputer, aplikasi SIMDA, dan jaringan internet. Aplikasi SIMDA di instal kan ke dalam komputer sesuai petunjuk pemakaian yang dikeluarkan oleh BPKP. Setelah di instal komputer harus dikoneksikan ke server lewat jaringan internet.

SDM yang dimiliki kurang sesuai dengan bidang pengelolaan keuangan SIMDA tersebut karena tenaga kontrak yang bekerja dalam mengoperasikan aplikasi SIMDA keuangan kurang mendapatkan pelatihan khusus dari Pemerintah Kabupaten Muna Barat, pelatihan pengoperasian SIMDA keuangan terakhir dilaksanakan pada tahun 2016 dikantor BPKP Sulawesi Tenggara. Dalam lembaga pemerintah daerah sumber daya manusia harus mendapat manajemen pengolahan yang baik melalui pendidikan dan pelatihan-pelatihan sehingga nantinya akan dapat memberikan manfaat terhadap pemerintah daerah. Hal ini terlebih lagi adanya problem antara dasar pendidikan Teknologi Informasi dengan dasar pendidikan Akuntansi. Seorang operator dengan 
Jurnal Akuntansi dan Keuangan (JAK)

Volume 6, No. 2 Oktober Tahun 2021

Page: 180 - 196

http://ojs.uho.ac.id/index.php/jak-uho/issue/archive

e-ISSN: 2088-4656

pendidikan Teknologi Informasi mungkin dapat sangat memahami SIMDA namun kurang paham dalam segi akuntansi. Sementara itu, seorang operator dengan latar akuntansi dapat bermasalah dengan Teknologi Informasi. Karena tidak bertopang pada latar belakang pendidikan formal, maka kompetensi dari SDM SIMDA harus selalu melakukan Pelatihan. Pelatihan dilakukan oleh pemerintah daerah Kabupaten Muna Barat dengan berkoordinasi BPKP sebagai pemegang hak cipta dari SIMDA.

Dengan penerapan SIMDA sebagai sistem akuntansi Keuangan daerah mempengaruhi kualitas laporan keuangan Pemerintah Daerah Kabupaten Muna Barat. Staf Akuntansi BPKAPD menjelaskan bahwa keterbatasan aplikasi yang dimiliki hanya dapat melakukan penginputan akuntansi penerimaan kas (STS/ Nota Kredit/ Bukti Lainnya, R/C) , akuntansi pengeluaran kas (Tindasan SP2D/ Bukti Lainnya, R/C) dan Akuntansi selain kas. Untuk menghasilkan laporan keuangan, aplikasi SIMDA hanya dapat mengeluarkan Laporan Realisasi Anggaran, selebihnya disusun secara manual menggunakan Microsoft Excel.

Walaupun banyaknya keterbatasan yang dimiliki dalam pengelolaan Sistem Akuntansi Keuangan Daerah, Badan Pengelolaan Keuangan Aset \& Pendapatan Daerah telah melakukan pengelolaan keuangan sesuai dengan PP nomor 71 tahun 2010 tentang standar akuntansi pemerintah yang disesuaikan dengan Permendagri nomor 13 tahun 2006 tentang pedoman pengelolaan keuangan daerah dan Permendagri nomor 64 tahun 2013 tentang penerapan akuntansi pemerintah berbasis akrual pada pemerintah daerah.

Analisis Penyajian Laporan Keuangan SKPD Badan Pengelolaan Keuangan Aset \& Pendapatan Daerah

1. Laporan Realisasi Anggaran

Berdasarkan data penelitian Laporan Realisasi Anggaran Badan Pengelolaan Keuangan Aset dan Pendapatan Daerah Kabupaten Muna Barat Tahun Anggaran 2019 menyajikan pos laporan keuangan sebagai berikut:

a. Pendapatan LRA

Pendapatan Asli Daerah (PAD) yang terdiri dari :

- Pendapatan Pajak Daerah

- Pendapatan Hasil Pengelolaan Kekayaan Daerah Yang Dipisahkan

- Lain-lain PAD yang Sah

Dibandingkan dengan realisasi Tahun 2018, realisasi PAD Tahun 2019 lebih kecil Rp1.644.314.274,00 atau turun 11,09\%.

b. Belanja

Belanja Operasi yang terdiri dari :

- Belanja Pegawai

- Belanja Barang dan Jasa

Belanja Modal yang terdiri dari :

- Belanja Modal Peralatan dan Mesin 
Jurnal Akuntansi dan Keuangan (JAK)

Volume 6, No. 2 Oktober Tahun 2021

Page: 180 - 196

http://ojs.uho.ac.id/index.php/jak-uho/issue/archive

e-ISSN: 2088-4656

Apabila dilihat dari Anggaran Belanja Daerah pada Perubahan APBD Tahun

Anggaran 2019 sebesar Rp34.522.140.426,00 maka realisasi Tahun Anggaran 2019 sebesar Rp15.732.169.502,00 atau 45,57\%.

c. Surplus / Defisit

d. Sisa Lebih Pembiayaan Anggaran (SILPA)

Berdasarkan pos-pos Laporan Realisasi Anggaran di SKPD menurut PSAP 01 dan Permendagri nomor 64 tahun 2013 sudah memenuhi kelengkapan Laporan Realisasi Anggaran.

\section{Laporan Operasional}

Berdasarkan data penelitian Laporan Operasional Badan Pengelolaan Keuangan Aset dan Pendapatan Daerah Kabupaten Muna Barat Tahun Anggaran 2019 menyajikan pos laporan keuangan sebagai berikut:

a. Pendapatan LO

Pendapatan Asli Daerah (PAD) yang terdiri dari :

- Pendapatan Pajak Daerah

- Pendapatan Hasil Pengelolaan Kekayaan Daerah Yang Dipisahkan

- Lain-lain PAD yang Sah

Pada tahun 2019 Pendapatan-LO SKPD Badan Pengelola Keuangan, Aset dan Pendapatan Daerah direalisasikan sebesar Rp12.788.413.418,00 apabila dibandingkan dengan Pendapatan-LO pada Tahun 2018 sebesar Rp15.410.499.336,00 maka terjadi penurunan sebesar Rp195.301.338,00 atau $1,27 \%$.

b. Beban

Beban Operasi yang terdiri dari :

- Beban Pegawai - LO

- Beban Barang dan Jasa

- Beban Persediaan

- Beban Penyusutan dan Amortisasi

- Beban Penyisihan Piutang

Selama tahun 2019, beban SKPD Badan Pengelola Keuangan, Aset dan Pendapatan Daerah adalah sebesar Rp15.532.240.613,54 dan apabila dibandingkan dengan realisasi Tahun 2018 sebesar Rp10.080.580.287,00 maka mengalami peningkatan sebesar Rp5.451.660.326,54 atau 54,08\%.

c. Surplus / Defisit dari Kegiatan Operasional

d. Defisit Non Operasional

e. Surplus / Defisit Sebelum Pos Luar Biasa

f. Pos Luar Biasa

g. Beban Luar Biasa

h. SURPLUS/DEFISIT LO 
Jurnal Akuntansi dan Keuangan (JAK)

Volume 6, No. 2 Oktober Tahun 2021

Page: 180 - 196

http://ojs.uho.ac.id/index.php/jak-uho/issue/archive

e-ISSN: 2088-4656

Berdasarkan pos-pos Laporan Operasional di SKPD menurut PSAP 01 dan Permendagri nomor 64 tahun 2013 sudah memenuhi kelengkapan Laporan Operasional.

\section{Neraca}

Berdasarkan data penelitian Neraca Badan Pengelolaan Keuangan Aset dan Pendapatan Daerah Kabupaten Muna Barat Tahun Anggaran 2019 menyajikan pos laporan keuangan sebagai berikut:

a. Aset

Aset Lancar yang terdiri dari :

- Kas di bendahara penerimaan

- Kas di bendahara pengeluaran

Saldo Kas di Bendahara Pengeluaran berupa uang tunai maupun yang berada di rekening giro bank bendahara pengeluaran SKPD Badan Pengelola Keuangan, Aset dan Pendapatan Daerah per 31 Desember 2019 adalah sebesar Rp234.869.950,00.

- Piutang Pendapatan

Piutang Pendapatan per 31 Desember 2019 Badan Pengelola Keuangan, Aset dan Pendapatan Daerah sebesar Rp1.905.560.110,00 yang merupakan piutang PBB yang belum tertagih sebesar Rp1.587.248.408,00, piutang pajak minerba tahun 2019 sebesar Rp57.154.879,00, piutang denda pajak minerba sebesar Rp15.469.386,00, dan piutang pajak penerangan jalan tahun 2019 sebesar Rp85.834.563,00, serta sisa piutang pajak minerba tahun 2018 yang belum diterima sebesar Rp159.852.874,00 karena yang diterima tahun 2019 sebesar Rp7.583.001,00 dari total piutang sebesar Rp167.435.875,00.

- Penyisihan Piutang

- Persediaan

Saldo akun ini menggambarkan jumlah persediaan barang yang mempunyai sifat habis pakai dan diperoleh dengan maksud untuk mendukung kegiatan operasional Pemerintah Daerah, serta barang yang dimaksudkan untuk dijual/diserahkan dalam rangka pelayanan masyarakat yang masih berada di Satuan Kerja. saldo akhir persediaan per 31 Desember 2019 dan 31 Desember 2018 di SKPD Badan Pengelola Keuangan, Aset dan Pendapatan Daerah sebesar Rp10.818.500,00. Persediaan dinilai berdasarkan hasil perhitungan fisik (stock opname) terhadap persediaan dengan menggunakan harga perolehan terakhir dan/atau nilai wajar yang ditetapkan oleh pengurus barang SKPD Badan Pengelola Keuangan, Aset dan Pendapatan Daerah.

Aset Tetap yang terdiri dari : 
Jurnal Akuntansi dan Keuangan (JAK)

Volume 6, No. 2 Oktober Tahun 2021

Page: 180 - 196

http://ojs.uho.ac.id/index.php/jak-uho/issue/archive

e-ISSN: 2088-4656

- Tanah

- Peralatan dan mesin

- Gedung dan bangunan

- Jalan, Irigasi, dan Jaringan

- Aset tetap lainnya

- Konstruksi dalam Pengerjaan

- Akumulasi Penyusutan

Telah dibahas dalam fenomena saya bahwasanya Pengakuan nilai aset tetap BPKAPD berupa tanah, peralatan \& mesin, gedung \& bangunan, jalan, irigasi, \& jaringan, aset tetap lainnya, dan konstruksi dalam pengerjaan berjumlah nol ini disebabkan karena Aset tetap yang ditempati BPKAPD tidak dimiliki secara resmi atau masih dipinjam dari Pemerintah Kabupaten Muna Barat sehingga pencatatan nilai aset tetap yang dipakai dicatat di Laporan Neraca Sekretariat Kabupaten Muna Barat.

Aset Lainnya

Akun ini menggambarkan nilai tagihan penjualan angsuran, tuntutan ganti rugi, piutang retribusi, aset tak berwujud dan aset lain-lain dengan rincian saldo per 31 Desember 2019 dan 31 Desember 2018.

b. Kewajiban

Kewajiban Jangka Pendek yang terdiri dari :

- Utang Perhitungan Pihak Ketiga (PFK)

Kewajiban Jangka Panjang yang terdiri dari :

- Utang Dalam Negeri

c. Ekuitas

Berdasarkan pos-pos Laporan Neraca di SKPD menurut PSAP 01 dan Permendagri nomor 64 tahun 2013 sudah memenuhi kelengkapan Laporan Neraca.

\section{Laporan Perubahan Ekuitas}

Berdasarkan data penelitian Laporan Perubahan Ekuitas Badan Pengelolaan Keuangan Aset dan Pendapatan Daerah Kabupaten Muna Barat Tahun Anggaran 2019 menyajikan pos laporan keuangan sebagai berikut:

a. Ekuitas Awal

Ekuitas Awal SKPD Badan Pengelola Keuangan, Aset dan Pendapatan Daerah Tahun 2019 adalah sebesar Rp4.147.567.566,00. Nilai ini merupakan Ekuitas Akhir Tahun 2018.

b. Surplus / Defisit - LO

Surplus/Defisit-LO SKPD Badan Pengelola Keuangan, Aset dan

Pendapatan Daerah Tahun 2019 adalah sebesar (Rp2.743.827.195,54)

yang dihasilkan dari transaksi menutup akun Surplus/Defisit-LO.

c. Dampak Kumulatif Perubahan Kebijakan/Kesalahan Mendasar 
Jurnal Akuntansi dan Keuangan (JAK)

Volume 6, No. 2 Oktober Tahun 2021

Page: 180 - 196

http://ojs.uho.ac.id/index.php/jak-uho/issue/archive

e-ISSN: 2088-4656

Dampak Kumulatif Perubahan Kebijakan/Kesalahan Mendasar Pemerintah Kabupaten Muna Barat Tahun 2019 pada Badan Pengelola Keuangan, Aset dan Pendapatan Daerah sebesar Rp34.111.667,00 merupakan koreksi saldo awal penyusutan.

d. Koreksi Saldo Awal Akumulasi Penyusutan

e. Kewajiban Untuk di Konsolidasi kan

f. Ekuitas Akhir

Berdasarkan pos-pos Laporan Perubahan Ekuitas di SKPD menurut PSAP 01 dan Permendagri nomor 64 tahun 2013 sudah memenuhi kelengkapan Laporan Perubahan Ekuitas.

\section{Catatan Atas Laporan Keuangan}

Berdasarkan data penelitian Catatan atas Laporan Keuangan Pemerintah Kabupaten Muna Barat Tahun 2019 memuat penjelasan dan atau catatan atas laporan keuangan dalam periode Tahun Anggaran 2019 yang disusun dengan sistematika sebagai berikut:

Bab I Pendahuluan

1.1 Maksud dan tujuan penyusunan Laporan Keuangan

1.2 Landasan Hukum Penyusunan Laporan Keuangan

1.3 Sistematika Penulisan Catatan atas Laporan Keuangan.

Bab II Ikhtisar Pencapaian Kinerja Keuangan Pemerintah Daerah

2.1 Ikhtisar realisasi pencapaian target kinerja keuangan

2.2 Hambatan dan kendala yang ada dalam pencapaian target yang telah ditetapkan. Bab III Penjelasan Pos-pos Laporan Keuangan

3.1 Laporan Realisasi Anggaran

3.1.1 Pendapatan LRA

3.1.2 Belanja

3.2 Neraca

3.2.1 Aset

3.2.2 Kewajiban

3.2.3 Ekuitas

3.3 Laporan Operasional

3.3.1 Pendapatan LO

3.3.2 Beban

3.3.2 Surplus / Defisit Kegiatan Operasional

3.4 Laporan Perubahan Ekuitas

3.4.1 Ekuitas Awal

3.4.2 Surplus / Defisit LO

3.4.3 Dampak Kumulatif Perubahan Kebijakan/Kesalahan Mendasar

Ekuitas Akhir

Bab IV Penjelasan atas Informasi - informasi Non Keuangan. 
Jurnal Akuntansi dan Keuangan (JAK)

Volume 6, No. 2 Oktober Tahun 2021

Page: 180 - 196

http://ojs.uho.ac.id/index.php/jak-uho/issue/archive

e-ISSN: 2088-4656

Bab V Penutup.

Berdasarkan Item-item Catatan Atas Laporan Keuangan di SKPD menurut psap 01 dan Permendagri nomor 64 tahun 2013 sudah memenuhi kelengkapan Catatan Atas Laporan Keuangan.

\section{KESIMPULAN, IMPLIKASI, KETERBATASAN, DAN REKOMENDASI}

\section{a. Kesimpulan}

Berdasarkan hasil analisis data dan temuan-temuan yang diperoleh, maka dapat disimpulkan bahwa:

1. Dalam menjalankan tugas dan fungsi pokok di bidang pengelolaan keuangan daerah yang efektif, akurat, dan transparan Badan Pengelolaan Keuangan Aset dan Pendapatan Daerah menggunakan Aplikasi SIMDA Keuangan dan Microsoft Excel yang membantu pengelolaan data keuangan pemerintah daerah. Penerapan SIMDA Keuangan sebagai Sistem Akuntansi Keuangan Daerah di Badan Pengelolaan Keuangan Aset dan Pendapatan Daerah Kabupaten Muna Barat saat ini belum begitu efektif. Hal tersebut terkait dengan masalah infrastruktur berupa jaringan dan fasilitas yang memadai dan masalah kesiapan Sumber Daya Manusia. Walaupun SIMDA Keuangan belum efektif diterapkan akan tetapi penerapan Sistem Akuntansi Keuangan Daerah telah sesuai dengan ketentuan yang terdapat dalam Peraturan Pemerintah Nomor 71 Tahun 2010 tentang Standar Akuntansi Pemerintah dan Peraturan Menteri Dalam Negeri Nomor 64 Tahun 2013 tentang Penerapan Standar Akuntansi Pemerintahan Berbasis Akrual Pada Pemerintah Daerah.

2. Penyusunan Laporan Keuangan SKPD BPKAPD yang terdiri dari : 1) Laporan Realisasi Anggaran, 2) Laporan Operasional 3) Neraca, 4) Laporan Perubahan Ekuitas 5) Catatan Atas Laporan Keuangan pada Badan Pengelolaan Keuangan Aset dan Pendapatan Daerah Kabupaten Muna Barat dimana format dan uraian perkiraan telah diklasifikasikan sesuai dengan Peraturan Pemerintah Nomor 71 Tahun 2010 tentang Standar Akuntansi Pemerintah (PSAP 01) dan Peraturan Menteri Dalam Negeri Nomor 64 Tahun 2013 tentang Penerapan Standar Akuntansi Pemerintahan Berbasis Akrual Pada Pemerintah Daerah.

\section{b. Implikasi}

Berdasarkan hasil analisis dan pembahasan, menunjukkan bahwa pentingnya usaha untuk meningkatkan fasilitas yang memadai berupa infrastruktur dan Sumber Daya Manusia yang merupakan faktor pendukung keberhasilan dalam menerapkan Sistem Akuntansi Keuangan Daerah.

c. Keterbatasan Penelitian 
Jurnal Akuntansi dan Keuangan (JAK)

Volume 6, No. 2 Oktober Tahun 2021

Page: 180 - 196

http://ojs.uho.ac.id/index.php/jak-uho/issue/archive

e-ISSN: 2088-4656

Penelitian ini hanya menggunakan Laporan Keuangan SKPD pada BPKAPD , sebaiknya peneliti selanjutnya menggunakan Laporan Keuangan SKPD dan SKPKD untuk bagaimana menjelaskan 2 fungsi BPKAPD sebagai entitas akuntansi dan entitas pelaporan.

\section{d. Rekomendasi}

Berdasarkan hasil analisis yang telah dilakukan mengacu pada kesimpulan di atas, maka dapat diberikan saran-saran yang nantinya diharapkan dapat memperbaiki ataupun menyempurnakan penerapan Sistem Akuntansi Keuangan Daerah di Badan Pengelolaan Keuangan Aset dan Pendapatan Daerah Kabupaten Muna Barat. Adapun saran-saran yang dimaksud adalah :

1. Berfokus pada peningkatan kualitas Infrastruktur dan Sumber Daya Manusia yang dimiliki dengan cara memberikan fasilitas yang memadai, serta gencar memberikan sosialisasi pelatihan secara berkala kepada SDM kemudian pada saat proses pengoperasian harus berkelanjutan agar pengalaman \& data tetap terjaga dengan baik, dan menambah jumlah SDM terutama yang mempunyai basic pengetahuan komputer serta yang memiliki latar belakang pendidikan akuntansi khususnya akuntansi pemerintahan agar penerapan Sistem Akuntansi Keuangan Daerah dapat berjalan optimal.

2. Untuk penelitian berikutnya, dapat ditambahkan indikator baru untuk memperkaya model yang digunakan pada penelitian ini. Dengan demikian hasil penelitian berikutnya dapat lebih sempurna dan kesimpulan yang diperoleh dapat berubah lebih baik atau tetap sama dengan penelitian ini.

\section{Daftar Pustaka}

Bahtiar, Arif, Iskandar, Muchlis. 2009. Akuntansi Pemerintah. Akademia. Jakarta.

Bastian Indra, 2011. Akuntansi Sektor Publik. Edisi ke-tiga. Erlangga. Indonesia.

Bodnar, George H. dan Hopwood, William S. Diterjemahkan oleh Amir Abadi Yusuf dan Andi M. Tambunan, 2008. Sistem informasi Akuntansi, Salemba Empat, Jakarta.

Erlina, Omar Sakti Rambe, dan Rasdianto. 2015. Akuntansi Keuangan Daerah Berbasis Akrual Berdasarkan PP No. 71 Tahun 2010 dan Permendagri No.64 Tahun 2013. Jakarta. Salemba Empat.

Halim Abdul, 2012. Akuntansi Sektor Publik, Teori Konsep dan Aplikasi. Jilid 1. Salemba Empat. Indonesia.

Mulyadi. 2013.Sistem Akuntansi, Edisi Ketiga, Cetakan Keempat, Salemba Empat, Jakarta.

Republik Indonesia. 2004. Undang-Undang Nomor 33 Tahun 2004. Tentang Perimbangan Keuangan antara Pemerintah Pusat dan Pemerintah Daerah. Jakarta: Pemerintah RI 
Jurnal Akuntansi dan Keuangan (JAK)

Volume 6, No. 2 Oktober Tahun 2021

Page: 180 - 196

http://ojs.uho.ac.id/index.php/jak-uho/issue/archive

e-ISSN: 2088-4656

Republik Indonesia. 2014. Undang-Undang Nomor 23 Tahun 2014. Tentang Pemerintah Daerah. Jakarta: Pemerintah RI

Republik Indonesia. 2010. Peraturan Pemerintah Nomor 71 Tahun 2010. Tentang Standar Akuntansi Pemerintah. Jakarta: Pemerintah RI

Republik Indonesia. 2011. Peraturan Menteri Dalam Negeri nomor 21 tahun 2011. Tentang perubahan kedua atas Peraturan Menteri Dalam Negeri nomor 13 tahun 2006 tetntang pedoman pengelolaan keuangan daerah. Jakarta: Pemerintah RI

Republik Indonesia. 2013. Peraturan Menteri Dalam Negeri Nomor 64 Tahun 2013. Tentang Penerapan Standar Akuntansi Pemerintah Berbasis Akrual. Jakarta: Pemerintah RI

Republik Indonesia. 2017. Peraturan Bupati Muna Barat Nomor 30 Tahun 2017. Tentang Kedudukan, Tugas Pokok dan Fungsi Serta Tata Kerja Badan Pengelolaan Keuangan, Aset, dan Pendapatan Daerah Kabupaten Muna Barat. Muna Barat: Pemerintah RI

Sugiyono. 2008. Metode Penelitian Kuantitatif Kualitatif dan R\&D. Bandung : ALFABETA

Winwin Yadiati dan Ilham Wahyudi, 2006, Pengantar Akuntansi. Kencana Prenada Media Group, Jakarta. 